International Journal of Instruction e-ISSN: 1308-1470 • www.e-iji.net

Article submission code: 20200718042951

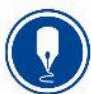

October $2021 \bullet$ Vol.14, No.4

p-ISSN: 1694-609X

pp. 187-208

Received: $18 / 07 / 2020$

Revision: 03/03/2021
Accepted: 26/03/2021

OnlineFirst: 17/07/2021

\title{
E-module in Blended Learning: Its Impact on Students' Disaster Preparedness and Innovation in Developing Learning Media
}

\section{Sumarmi}

Prof., Faculty of Social Sciences, State University of Malang, Indonesia, sumarmi.fis@um.ac.id

\section{Syamsul Bachri}

Ph.D, Faculty of Social Sciences, State University of Malang, Indonesia, syamsul.bachri.fis@um.ac.id

\section{Listyo Yudha Irawan}

M.Sc, Faculty of Social Sciences, State University of Malang, Indonesia, listyo.fis@um.ac.id

\section{Muhammad Aliman}

Dr, Faculty of Social Sciences, State University of Malang, Indonesia, alviageo@gmail.com

\begin{abstract}
E-module was used as a guide to activities in the blended learning process. The purpose of this study was (1) to find out the implementation of learning using emodules with blended learning, (2) to determine the effect of using e-module with blended learning on student disaster preparedness, (3) to determine the effect of using e-module with blended learning on student innovation in designing learning media. The research method was quasi-experiment using pretest-posttest with nonequivalent control group design and independent sample $\mathrm{t}$-test as data analysis. The research subject was the third-year students from geography department of 2017. The measurement of disaster preparedness and innovation in designing learning media used essay and assessment rubric. The results showed that there was an influence and compatibility of e-modules with blended learning on student disaster preparedness as well as in designing learning media and students were most interested in floods, earthquakes, and COVID-19.
\end{abstract}

Keywords: e-module, blended learning, disaster preparedness, learning media, learning

\section{INTRODUCTION}

Indonesia is a country with high-risk of natural disastres (Bachri et al., 2015a, 2019, 2020; Sholihah et al., 2019; Suharto et al., 2020). The disaster was caused by geological, geomorphological, climatological and antropogenic factors. Therefore,

Citation: Sumarmi., Bachri, S., Irawan, L. Y., \& Aliman, M. (2021). E-module in Blended Learning: Its Impact on Students' Disaster Preparedness and Innovation in Developing Learning Media. International Journal of Instruction, 14(4), 187-208. https://doi.org/10.29333/iji.2021.14412a 
disaster preparedness are needed to survive in the vulnerable area are needed for students to survive.

Students in disaster management course was chosen as research subject because they were expected to have a better understand of disaster management and be able to relate theory to real conditions in interpreting local disasters. It is necessary to have teaching materials that to meet learning outcomes effectively, therefore this study used e-modules as teaching materials (Sugiani et al., 2019). Aside from curriculum needs, the graduates from disaster management courses, were also expected to be responsive to technological developments, so the e-modules chosen can be applied in blended learning. It is because some material was in the images and videos form that taken from the surrounding environment, mainly based on disasters that occur in Indonesia. If the images inserted into the print e-module, then will add more expensive costs and often the result is less clear. For that reason, choosing digital e-modules applied in blended learning using Moodle (a learning platform or course management system) was the right choice to improve disaster management learning materials which currently needs a lot of improvement.

The purpose of the disaster management course was to understand geography as a science and study, objects, approaches and principles. Also, this course aimed for students to be able to design and apply innovative ideas in geography education research for solving educational and learning problems, be skilled at communicating the work both orally and in writing and be able to appreciate research practice as an inspiration and development of research ideas (Sumarmi et al., 2020). Furthermore, the objectives were specified such as (1) students can study the phenomenon of disaster through the understanding of disaster risk including physical and social components, (2) students can do a learning project by arranging learning media related to disaster management.

The learning material developed in e-modules was such as the study of Indonesia as a disaster-prone country, types of disasters in Indonesia (Abdillah et al., 2020), geographical contributions of disaster, terminology in disaster management, risk studies, hazard studies, vulnerability and capacity, learning models for disaster and project design of disaster education (Shah et al., 2018). The material in this e-module was completed with sample images from disasters in various regions in Indonesia.

Disaster education can begin with a comprehensive understanding of the disaster characteristics and the processes involved. The disaster process can be understood as a whole through learning the basic concepts of disaster risk management consisted of components of hazard, vulnerability and community capacity (Rachmawati et al., 2018). The components of disaster risk included, 1) hazard as an atmospheric, geophysical, or hydrological event that has the potential to cause harm or damage, 2) vulnerability as a condition that is threatened by damage or loss, 3 ) capacity as a combination strength and completeness of community resources, social groups, and social organizations that can be used for agreed purposes, including matters relating to disaster risk reduction, 4) risk management, considered capable as a basic understanding of the disaster process in an area because it involves various physical and social components in the affected area (Bachri et al., 2015a, 2019, 2020). This concept also accommodates the complete 
handling process of a disaster event, as shown in figures 1 and 2. Besides, the concept of disaster risk management also has a complete process from risk analysis, risk evaluation to risk management seen in figure 2 .

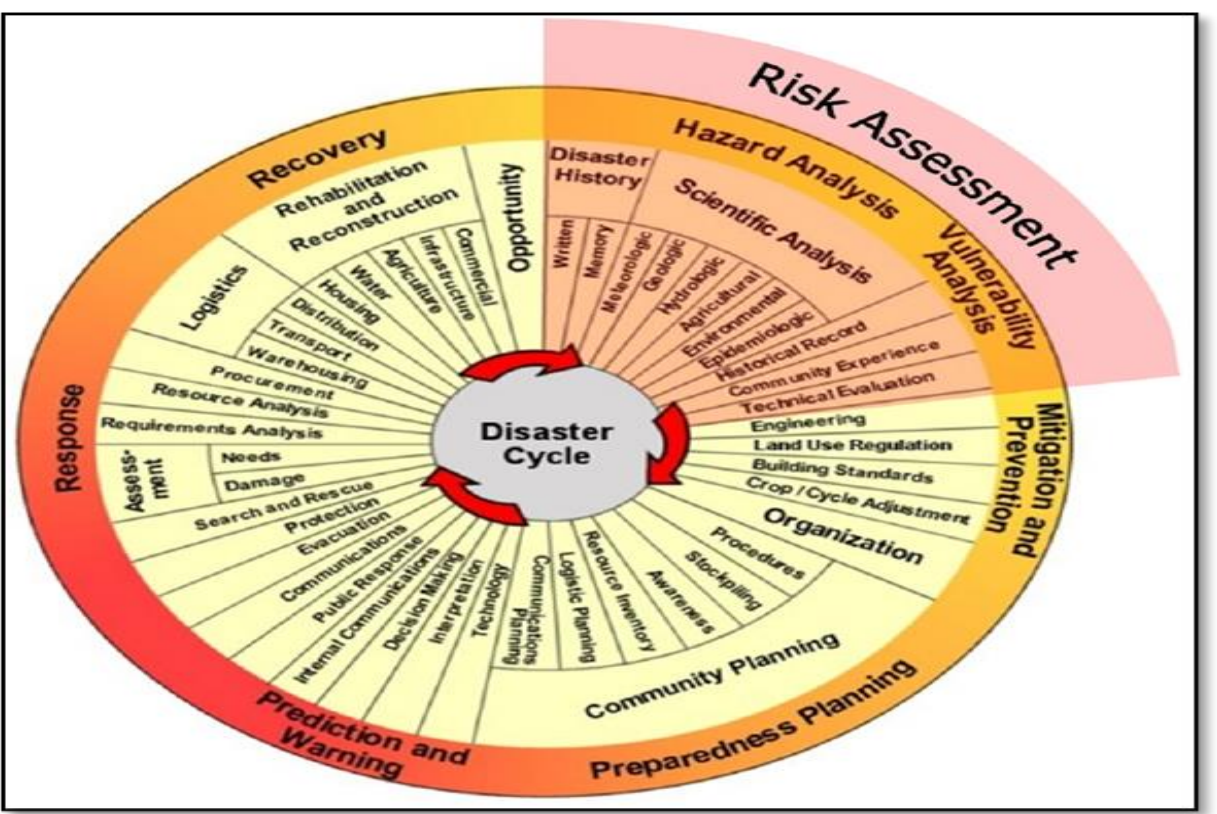

Figure 1

The role of risk assessment (S. Bachri et al., 2015b; Westen \& Montoya, 2011).

Based on Figure 1 showed that disaster risk reduction must apply risk management to determine the disaster character. Also, community preparedness, prevention, disaster prediction, community response, and post-disaster recovery are essential in disaster management (Westen \& Montoya, 2011). Risk reduction management requires a booster system to control the whole program. The following picture showed a holistic concept in disaster risk management. 


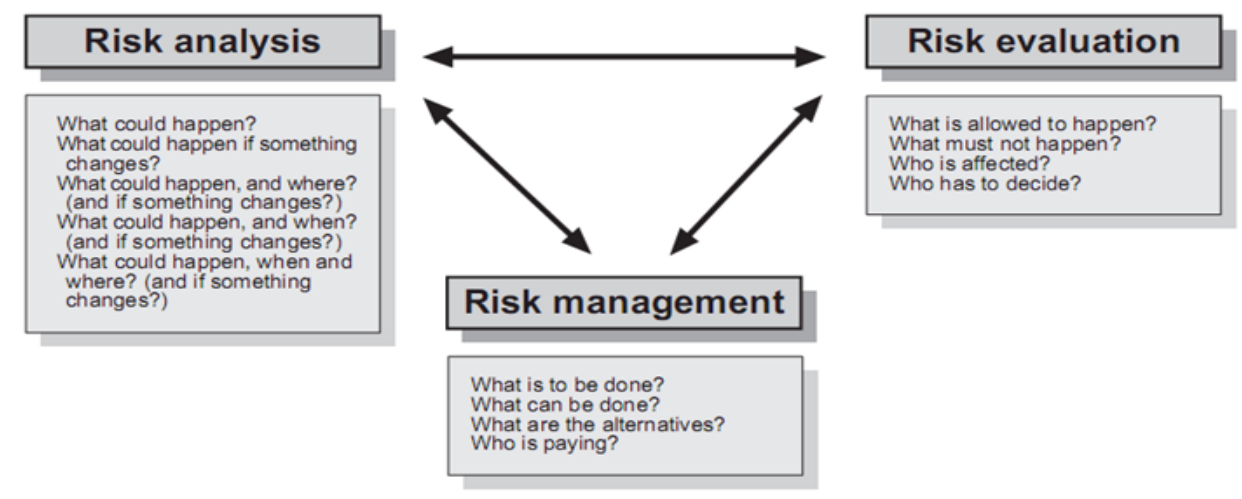

Figure 2

A holistic concept in disaster management risk assessment (Bachri et al., 2015a)

Based on Figure 2 explained that disaster risk reduction has three main concepts. The concepts are interrelated and mutually correlated. Therefore, management must provide a balance between the three concepts (Bachri et al., 2015b; Westen \& Montoya, 2011). One of the three concepts of disaster risk management is preparedness. The use of emodules can facilitate preparedness capability.

This research used e-modules combined with blended learning to develop student disaster preparedness. Collaboration between disaster science and education studies is a solution discussed through this research. Disaster education is one of the steps in disaster management, which taught through meaningful learning with students.

To effectively increase learning outcomes in this course, this study used e-modules as learning resources. The use of e-modules provides a great opportunity for students to understand the topic, so that disaster preparedness knowledge and skills will be improved (Roe et al., 2010). Aside with the curriculum needs and the development of technology, e-modules were chosen because it has advantages such as, 1) easy to learn anytime and anywhere, 2) can display colourful pictures or photos, 3) easy to edit, 4) easily integrated with other learning which is blended learning (Ridwan et al., 2020; Roberts, 2009; Sorokin \& Rougier, 2018; Sukhothai Thammathirat Open University (STOU), 2019).

This course implemented a blended learning model in the learning process to facilitate the use of e-modules. It was chosen because blended learning has the advantages such as, a) can increase the access and convenience, b) can reduce costs (Garrison \& Vaughan, 2008; Ju \& Mei, 2018; Stein \& Graham, 2020), c) students can independently use the materials online, and teachers can add advance materials through the internet, $d$ ) learning activities carried out by students outside the classroom can be managed and controlled by the instructor (Lee et al., 2016; Nurkhin et al., 2020; Wichadee, 2017), e) can reach students in a large scope (potential to reach a global audience), f) can facilitate the improvement and storage of learning materials (easy updating of content as well as archivable capabilities) (Nonthamand, 2020; Wahyuni et al., 2019). 
Many research related to blended learning has been studied before. Blended learning can improve spatial thinking skills and geography learning outcomes (Amin et al., 2020; Otoluwa et al., 2020), research statistics courses (Ridwan et al., 2020), language learning (Ju \& Mei, 2018), accounting learning (Nurkhin et al., 2020), knowledge management learning (Suharyati et al., 2020), inclusive learning (Rasmitadila et al., 2020). Also, blended learning can build the capacity of teachers and students in multidisciplinary education (Lee et al., 2016), build motivation, oral skills and critical thinking (Budiarti et al., 2016; Rafiola et al., 2020; Rahardjanto et al., 2019; Sari et al., 2019; Suarsana \& Mahayukti, 2013; Wahyuni et al., 2019; Wichadee, 2017). Develop literacy skills and facilitate online discussions (Arizen \& Suhartini, 2020; Maryuningsih et al., 2019). Other research related to disaster preparedness includes volcanoes (Bachri et al., 2015b; Permana, 2020), floods (Bachri et al., 2020), landslides (Bachri et al., 2019; Maryanti et al., 2017), earthquakes (Sholihah et al., 2019), school communities (Lesmana \& Purborini, 2015; Rosyida \& Adi, 2017; Sumarmi et al., 2020).

Some previous research is still examining the application of blended learning in each subject and relation on cognitive abilities. However, this study examined the application of blended learning using e-module of disaster management to determine disaster preparedness and students' innovative abilities in designing learning tools. Therefore, this study aimed to 1) determine the application of blended learning using e-modules, 2) determine the effect of using blended learning with e-modules on student banana preparedness, 3) determine the effect of blended learning with e-modules on students' innovation abilities and designing learning media.

\section{METHOD}

\section{Research Design}

The research used quasi-experiment using pretest-posttest with non-equivalent control group design. This study has an independent variable which is e-module titled Disaster management combined with blended learning. Meanwhile, the dependent variable was disaster preparedness and innovation in designing learning media. The experimental design in this research shown in table 1.

Table 1

Experiment design

\begin{tabular}{llll}
\hline Group & Pretest & Treatment & Posttest \\
\hline Experiment (E) & $\mathrm{Q}_{1}$ & $\mathrm{X}$ & $\mathrm{Q}_{2}$ \\
\hline Control (C) & $\mathrm{Q}_{1}$ & - & $\mathrm{Q}_{2}$ \\
\hline Source: (Arikunto, 2010) & & \\
Description: & & \\
E: Experiment Class & & \\
C: Control Class & & \\
$\mathrm{Q}_{1}$ : initial measurement in the pretest & \\
Q2: final measurement in posttest & \\
X: Treatment e-module with blended learning & & \\
-: Learning by discussion and question-answer method &
\end{tabular}




\section{Participant}

The population in this study were students from Geography Department of 2017. The sample were the third-year students from disaster management course divided into four classes, namely A, B, K, and L, who came from the Geography Department majoring class of 2017. The control group from class $\mathrm{K}$ was 32 students, consists of 20 female and 12 male, and the experimental group from class L was 35 students, consists of 24 female and 11 male. Both classes $\mathrm{K}$ and $\mathrm{L}$ were chosen because they have the same ability, because both class have similar learning outcome scores seen from previous semester.

\section{Instrument and Procedures}

The variable of student disaster preparedness was measured using five questions in essay form, the instrument questions followed indicators of disaster preparedness, including procedures, stockpiling, awareness, resource inventory, logistic planning and communication planning (Westen \& Montoya, 2011). The indicators of innovation in designing learning tools consisted of the ability to design: basic competencies, teaching materials, learning media and learning evaluation tools (Sumarmi, 2012). While innovation in developing learning media was measured using assessment rubrics. The research used a questionnaire in Google Form consisting of 13 semi-open questions to find out the type of disaster that students are interested in doing disaster preparedness actions and to know the implementation of learning using e-modules with blended learning. The result then measured the presentage score of each questions. The validity result of the disaster preparedness using Cronbach's alpha was 0.671, and the innovation in designing leaning media was 0.728 . The validity result of the implementation emodule blended learning using Cronbach's alpha was 0.634. It showed that the instrument is fit to be collected.

\section{Data Analysis}

Before analysing a hypothesis, normality and homogeneity tests are used first before conducting a hypothesis test or prerequisite test. The measurement of normality prerequisite tests used the Shapiro-Wilk normality test to determine the distribution of data analysis. Homogeneity test measurements were used the Levene's test to test the equality of variances. Data analysis was measured using the independent sample t-test with a significance level of $5 \%$.

\section{FINDINGS}

\section{The Implementation of Learning Using E-Modules with Blended Learning}

E-module was created by a lecturer team of the disaster management course. It is prepared based on SAP to provide students with the knowledge and can plan disaster learning projects with the basic science of geography. Lecturers have provided Emodules on the learning management system (LMS) used by the university (https://sipejar.um.ac.id/). Learning disaster management courses were conducted for 16 meetings, which 3 meetings were in-class, and the rest 13 meetings were online. 
In-class meetings were held at meetings 1-3. At this meeting, students were given the objectives of the disaster management course. Also, students can access the e-module of disaster management from LMS (SIPEJAR). Lecturer motivates students to develop knowledge, attitudes and skills as prospective teachers. In the next meeting, the lecturer encourages students to have the innovation in designing learning media on disaster topic.

At meetings 4 and 6 , the learning is carried out using the university learning management system (LMS), namely (https://sipejar.um.ac.id/). At this online meeting, students were grouped to discuss the learning problems regarding disaster management topic for elementary, junior and senior high school., and then investigate and observe at the school. At meetings 7 to 8, each group reported the investigations and temporary observations result. At the 9th meeting, students conducted a midterm exam, and in the 10-15th meeting, each group presented and discussed the reports. The 16th meeting is a final semester exam to determine learning outcomes in disaster management courses.

The instrument of SAP for the disaster management course is filled during the midterm exam, while the instrument of disaster preparedness and the innovation in designing learning tools are given at the last meeting. The following is the compatibility of the lecture program in the control group showed in table 2.

Table 2

The compatibility of the lecture program in disaster management course on the control group

\begin{tabular}{cllll}
\hline The Compatibility & Frequency & Percentage & Weight & Score \\
\hline Strongly disagree & 1 & 3.13 & 1 & 1 \\
\hline Disagree & 0 & 0.00 & 2 & 0 \\
\hline Agree & 26 & 81.25 & 3 & 78 \\
\hline Strongly agree & 5 & 15.63 & 4 & 20 \\
\hline Total & 32 & 100.00 & & \\
\hline
\end{tabular}

From table 2 explained that 26 participants $(81.25 \%)$ agreed to the lecture program compatibility with the e-module. A total of 5 participants $(15.63 \%)$ stated strongly agree, and only 1 participant $(3.13 \%)$ stated that they did not agree with the lecture program compatibility for the e-module. Generally, students in control group were agreed that the e-module is compatible with the lecture program.

Then in table 3 showed the compatibility of the lecture program in Disaster management course on the experimental group. 
Table 3

The compatibility of the lecture program in disaster management course on the experimental group

\begin{tabular}{lllll}
\hline The compatibility & Frequency & Percentage & Weight & Score \\
\hline Strongly disagree & 2 & 5.71 & 1 & 2 \\
\hline Disagree & 1 & 2.86 & 2 & 2 \\
\hline Agree & 26 & 74.29 & 3 & 78 \\
\hline Strongly agree & 6 & 17.14 & 4 & 24 \\
\hline Total & 35 & 100.00 & & \\
\hline
\end{tabular}

From table 3 can be seen that the learning of Disaster management courses using emodules with blended learning gets $74.29 \%$ so it can be concluded that learning goes according to the planned program and $17.14 \%$ of students chosen it is very compatible with the program. Generally, students in experiment group were agreed that the emodule is compatible with the lecture program.

The following result explained the effect of using e-module with blended learning on student disaster preparedness.

\section{The Effect of Using E-Module with Blended Learning on Student Disaster Preparedness}

The difference test for the two independent sample groups was carried out using the independent sample t-test. Before testing, normality premises were tested using the Kolmogorov Smirnov test. If the data used does not meet the premises, a replacement test used the Mann Whitney test. The analysis hypothesis was as follows:

$\mathrm{H}_{0}$ : There is no significant mean difference between the groups.

$\mathrm{H}_{1}$ : There are significant mean differences between groups.

The following are the results of different tests between the experimental class and the control class in terms of disaster preparedness.

Table 4

the summary of different mean tests of students disaster preparedness

\begin{tabular}{llll}
\hline Group & Mean & St dev. & Significance of Normality \\
\hline \multicolumn{1}{c}{ Control } & 6.4063 & 3.27118 & 0.000 \\
\hline Experiment & 15.6286 & 4.34596 & 0.004 \\
\hline $\mathrm{Z}_{\text {count }}$ & & $=-6.191$ & \\
\hline $\mathrm{Z}_{\text {table }}(5 \%)$ & $=1.960$ & \\
\hline & & $=0.000$ & \\
\hline -value $\mathrm{Z}$ & & &
\end{tabular}

Then showed the mean of students disaster preparedness on graph 5. 


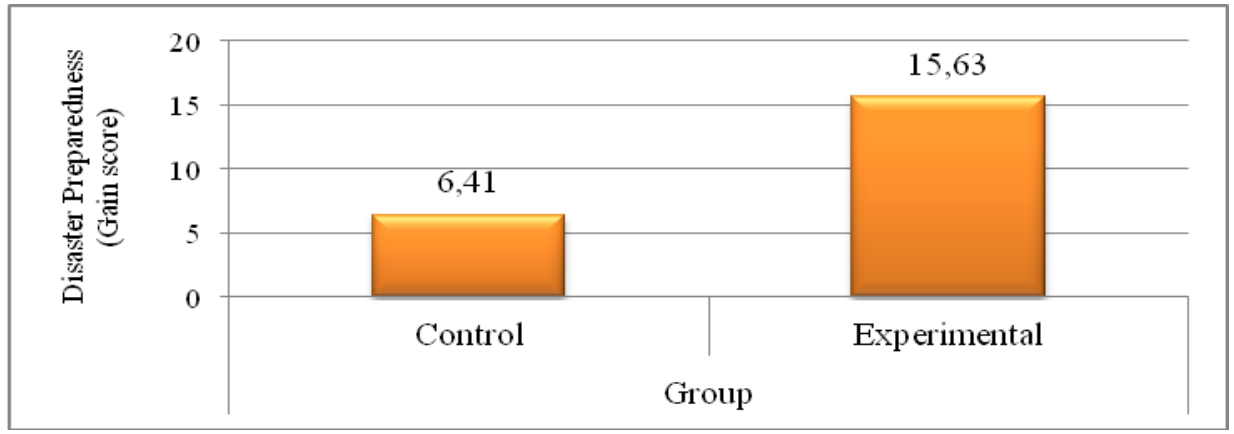

Graph 5

The mean value of students disaster preparedness

Based on the Kolmogorov Smirnov normality test, it was found that the control and experimental group data were not normally distributed with a significance value of less than $\alpha 5 \%$ each. Because it did not meet the premises, the Mann Whitney test was used.

From the Mann Whitney test, the calculated $\mathrm{Z}$ value was smaller than $-\mathrm{Z}_{\text {table }}(-6.191<-$

$1.960)$, and the $\rho$-value was lower than $\alpha(0.000<0.050)$. Then decided that $\mathrm{H}_{0}$ is rejected, which means that there was a significant mean difference between groups based on disaster preparedness gain score. Seen from Table 6, the mean gain score of the experimental group of disaster preparedness was higher than the control group score, and the difference was significant.

The following result explained the types of disasters that students are interested in measuring disaster preparedness.

The Types of Disasters that Student are interested in doing Disaster Preparedness Actions

The types of disasters that students are interested in doing disaster preparedness actions in the control group can be seen in Table 4.

Table 4

The types of disasters that students are interested in the control group

\begin{tabular}{lll}
\hline Phenomenon & Frequency & Percentage \\
\hline Volcanic eruption & 2 & 6.25 \\
\hline Landslide & 2 & 6.25 \\
\hline Flood & 12 & 37.50 \\
\hline Tsunami & 3 & 9.38 \\
\hline COVID-19 & 5 & 15.63 \\
\hline Earthquake & 7 & 21.88 \\
\hline Hydrometeorology & 1 & 3.13 \\
\hline Total & 32 & 100.00 \\
\hline
\end{tabular}


From table 4 can be explained that the phenomenon of disaster that students are interested in the control group to get the highest percentage is flooding $(37.50 \%)$, earthquake (21.88\%), and then COVID-19 (15.63\%).

Then explained the types of disasters that students are interested in doing disaster preparedness actions in the experimental group shown in Table 5.

Table 5

The types of disasters that students are interested in the experimental group

\begin{tabular}{lll}
\hline Phenomenon & Frequency & Percentage \\
\hline Volcanic eruption & 4 & 11.43 \\
\hline Landslide & 6 & 17.14 \\
\hline Flood & 11 & 31.43 \\
\hline Tsunami & 5 & 14.29 \\
\hline COVID-19 & 4 & 11.43 \\
\hline Earthquake & 5 & 14.29 \\
\hline Total & 35 & 100.00 \\
\hline
\end{tabular}

The phenomenon of disaster that students are interested in the experimental group shown in table 5 has more even distribution with the highest value owned by floods of $31.43 \%$ and landslides of $17.14 \%$, then followed by COVID-19 and earthquakes with the same percentage of $14.29 \%$.

The Effect of Using E-Module with Blended Learning on Student Innovation in Designing Learning Media

Beside the influence of e-modules with blended learning on student disaster preparedness, this study also aimed to determine the effect of e-modules with blended learning on student innovation in designing learning media. The following was the gain score result of the student innovation in designing learning media showed in table 7.

Table 7

The summary of different mean tests of student innovation in designing learning media

\begin{tabular}{lllc}
\hline Group & Mean & St dev. & Significance of Normality \\
\hline \multicolumn{1}{c}{ Control } & 4.7813 & 4.91695 & 0.133 \\
\hline Experiment & 14.5429 & 4.41483 & 0.200 \\
\hline $\mathrm{t}$ count & & $=-8.563$ & \\
\hline $\mathrm{t}$ table $(5 \%)$ & $=1.997$ & \\
\hline & & $=0.000$ & \\
$\rho$-value $\mathrm{t}$ & & & \\
\hline
\end{tabular}

Then showed the mean of student's innovation in designing learning media on graph 6 . 


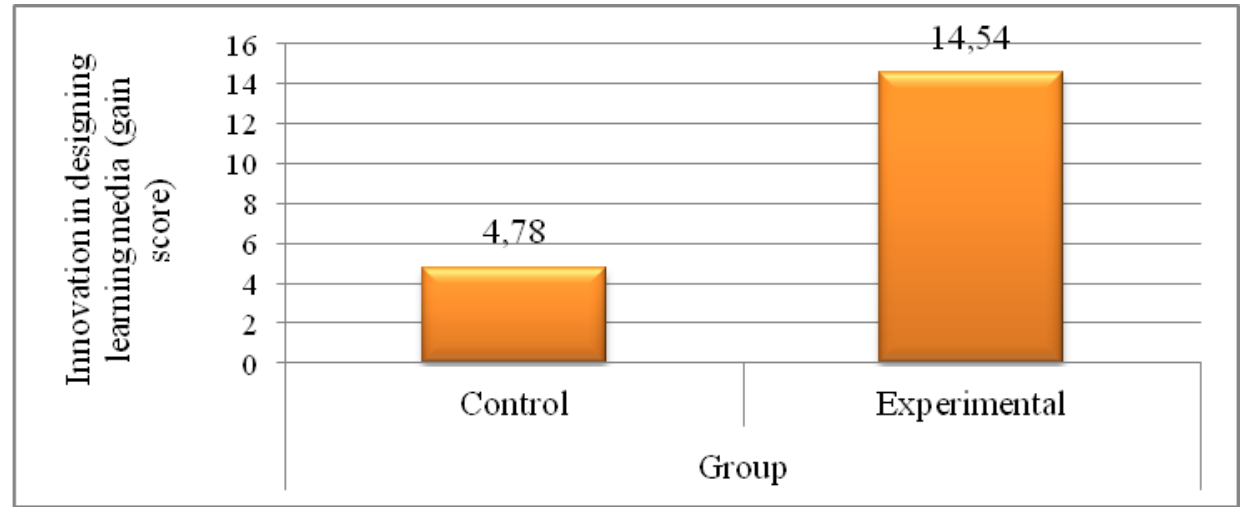

Graph 6

Mean value of student innovation in designing learning media

Based on the results of the Kolmogorov Smirnov normality test, it was found that data on the control group and the experimental group were normally distributed with a significance value more than $\alpha 5 \%$ each. Because it meets the premises, independence sample t-test was used instead.

From the independence sample t-test found that the calculated $\mathrm{t}$ value is higher than $\mathrm{t}$ table $(8,563>1,997)$, and the p-value is smaller than $\alpha(0,000<0.050)$. Then it is decided that $\mathrm{H} 0$ is rejected, which means there is a significant mean difference between groups based on the gain score of innovation in designing learning media. Based on table 7 and graph 6 shown that the mean gain score of the innovation in designing learning media on the experimental group was much higher than the gain score of the control group, and the difference is significant.

The innovation ability in designing learning media for disaster preparedness in the control group and the experimental group can be seen in graph 7 . 


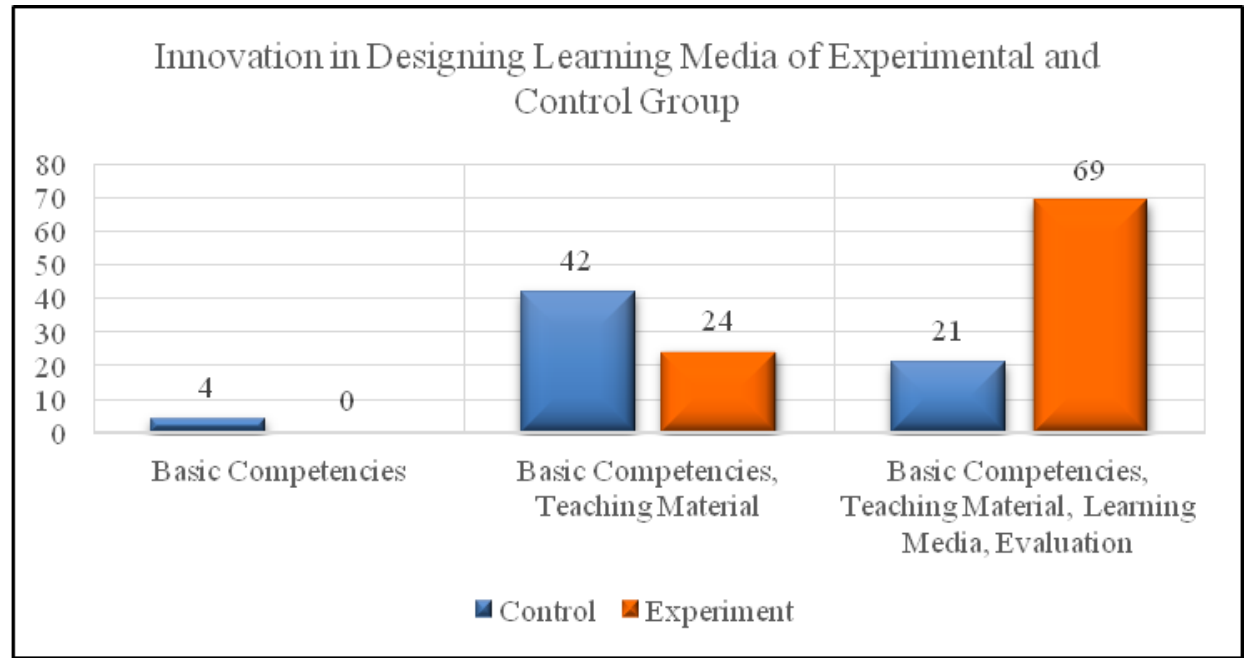

\section{Graph 7}

Students ability in designing learning media on the experimental and control group

Based on graph 7 explained that the ability of students in designing learning media on the control group was dominated by the ability to create only basic competencies (KD) and teaching materials with an average value of 42 . Furthermore, followed by the ability to create all learning necessities such as creating basic competencies (KD), making materials teaching, making learning media and creating evaluation measurement with an average value of 21 . The ability of students to create only basic competencies (KD) has an average value.

Based on graph 8 showed that the experimental class was dominated by the ability of students to create all learning necessities such as creating basic competencies (KD), making materials teaching, making learning media and creating evaluation measurement with an average value of 69 . The ability to create only basic competencies (KD) and teaching materials has a value of 24. It was confirmed that the ability of student innovation in designing learning media in the experimental class is higher than in the control class.

\section{DISCUSSION}

\section{The Implementation of Learning Using E-Modules with Blended Learning}

The research found that the implementation of learning using e-modules with blended learning can run well as planned in the lecture program (SAP) prepared at the beginning of the semester. Learning with e-modules has advantages such as, 1) easy to learn anytime and anywhere, 2) has images or photos that can be displayed in various colours, 3 ) easy to edit, and 4) easy to integrated with blended learning. 
The results also supported by the research (Suarsana \& Mahayukti, 2013; Sugiani et al., 2019) that stated the use of e-modules could improve learning outcomes and students' critical thinking skills. Student responses to e-modules in lectures were very positive. It is because the motivation given by lecturers at meetings can develop students potential (Bruning \& Horn, 2000). It is also supported by research (Budiarti et al., 2016; Marni et al., 2019) that learning with guide inquiry assisted by e-modules can improve students' critical thinking skills. Students found it very helpful in doing assignments assisted by emodules. Also, this study examined that the application of e-modules can improve disaster preparedness and innovation in designing learning media.

Blended learning is not only a modern lifestyle, but also can provide special benefits for students to improve access and comfort, improve the quality of learning, and reduce costs (Thomas, 2010). The advantage of online learning for students was that they no longer have to come to the actual class to take courses. For students who take school while working or have a family found that online learning was very helpful for them (Gibbons \& Woodside, 2014).

The use of technology to facilitate online learning activities can provide additional flexibility because students and lecturers can participate in comfortable learning. Improving information systems in blended learning is needed to achieve learning objectives (Burhendi et al., 2019). With a mobile phone or tablet could help and support online interaction anywhere, whether on the road, on public transportation or whenever users have free time. Some research on education showed that online learning was more effective than doing face to face learning (Garrison \& Vaughan, 2008; Ju \& Mei, 2018).

Online learning could increase student focus on relevant tasks through learning sites (Amin et al., 2020). It could also reduce costs for lecturers, students and universities. Lecturers and students can benefit from less travel time, transportation savings, and less parking fees. As for universities, the use of resources in schools could physically be reduced. Online learning cuts time by at least $50 \%$, so this reduction can provide significant savings for institutions that have problems maximizing classrooms physically (Stein \& Graham, 2020).

\section{The Effect of Using E-Module with Blended Learning on Student Disaster Preparedness}

The use of e-modules with blended learning has significant effects on student preparedness for disasters. It can be seen from the mean gain score of the experimental group was higher and significantly different from the control group. It was supported by the opinion that Indonesia is a country that is prone to various types of disasters, so that knowledge about the disaster is absolute to have (Bachri et al., 2015a). Geological, geomorphological, climatological and anthropogenic situations are factors that cause vulnerability in Indonesia.

The e-module of disaster management influenced the high score of disaster preparedness in the experimental group. The soft-printed of e-module was used by students so that it is easy to read anywhere and anytime. Students have a great opportunity to read and 
understand the e-module. Reading and understanding skills can provide knowledge and improve disaster preparedness attitudes (Rosyida \& Adi, 2017; Suharto et al., 2020).

The school preparedness outcomes were essential because Indonesia is a country with high disaster risk (Suharto et al., 2020). The data collected from school elements such as principals, teachers, and administrative staffs were needed to review school preparedness in disaster risk reduction. One of which was done in Magelang District, Central Java, Indonesia, which is threatened by lava from Mount Merapi. The survey results showed that school preparedness still needs to be improved (Sumarmi, 2017, 2018). Therefore, the learning to develop disaster preparedness still needed to be done in various ways, including using e-modules and blended learning (Suharto et al., 2020). Also, the application of blended learning could be effective and successful if the lecturer becomes a learning facilitator (Suharyati et al., 2020).

The results of the study (Rosyida \& Adi, 2017; Sumarmi et al., 2020) also revealed that students' knowledge about the flood was still lacking and the understanding of flood cause showed low. Students attitude to reduce the risk of flooding also quite low showed as they still playing and using electronics when flooding and the equipment were very minimal. Additional findings in this study were that there had been lessons about floods and how to overcome them, but they were not continued. The results indicated the level of disaster preparedness was in the "low" category with a percentage of $72 \%$. The results of other studies by (Maryanti et al., 2017) showed that the relationship between education and knowledge of landslide disaster preparedness in Giritirto Sub-district, Wonogiri Subdistrict, has a product-moment correlation value $r=1.0$, which is very high. Therefore, improvement in the e-module of floods, landslides, volcanic eruptions, and earthquakes was important to increase students' understanding to develop preparedness.

\section{The Types of Disasters that Students are Interested in doing Disaster Preparedness Actions}

The research concluded that the highest phenomenon of disaster that students are interested in the control group was flooding, then the earthquake, and COVID-19. While the phenomenon of disaster in the experimental group was more evenly distributed, with the highest was flooding, landslides, and then COVID-19 and earthquakes with the same percentage.

The flood was a disaster caused mainly by the human that does not support the environment. Other disaster phenomena such as landslides and earthquakes also have many factors that affect both natural and human factors. Earthquakes often occur in Indonesia because it is located at the meeting of 3 plates so that Indonesia is prone to earthquakes. Learning more about earthquake provided knowledge about how to mitigate the earthquakes, both structural and non-structural. The earthquake and tsunami are also interesting to study because it needed to know about geological conditions to find out the disaster caused. Besides, it could also learn other interrelated areas.

In addition to natural disasters, there is another non-disaster phenomenon that is currently interesting to study, namely COVID-19. Almost all the world feels this 
disaster, which has not yet found a cure. With this disaster phenomenon, it can be learned about how to prevent it, the causes of global spread and even the socioeconomic impacts that can be analysed to provide solutions in dealing with this disaster. The pandemic caused by the COVID-19 virus was a biological disaster that has had a very significant impact on human life in almost all over the world. Because it is a kind of new virus, information about the pandemic is very interesting to learn.

The eruption was also interesting because Indonesia has many volcanoes, which are the meeting of the Pacific Circum and the Mediterranean Circum. The volcano has been live along with surrounding communities. Therefore, there was needed the capacity of preparedness to handle the disaster such as regular counselling sessions, the standby team, and good knowledge about disasters in the community. Preparedness activities were essential to be carried out by Indonesian people (Lesmana \& Purborini, 2015; Sumarmi, 2015; Sumarmi et al., 2019). At present, the community still relies on information from the government and lacking in independence. However, the conditions differed in one region from another, and the types of disasters faced. Therefore, the local wisdom must be reinterpreted in order to grow perception and independence to face the volcanic eruptions (Permana, 2020).

\section{The Effect of Using E-Module with Blended Learning on Student Innovation in Designing Learning Media}

The ability of student innovation in designing learning media differed significantly between the control group and the experimental group. It can be seen from the mean gain score of the experimental group was higher and significantly different from the control group. The innovation of designing learning media starts from understanding the curriculum, describing basic components, designing teaching materials, designing learning models in the lesson plan (RPP), designing learning media, and making evaluations measurement.

Several factors caused the difference innovation in designing learning media using blended learning, namely the learning stages. In blended learning, the stage of organizing problem influenced students to learn to find out problems, especially in designing learning media (Amin et al., 2020). Also, the investigation and observation played a major role in students because students are given the option to find out important things needed in designing media (Budiarti et al., 2016). Then, at the stage of development, it is easier for students to make the learning media because the elements are already discussed in the previous process (Budiningarti et al., 2015). By understanding the elements and taking sufficient data from the field or secondary data from agencies related to the disaster, the more innovative the media arranged. Students can be creative in designing innovative learning media using student worksheets, modules, various digital media, and assessments that are not just written tests but instead use authentic assessment (Budiningarti et al., 2015; Delita et al., 2016; Muskania \& Wilujeng, 2017).

The results of this study are supported by research (Budiningarti et al., 2015; Sumarmi, 2012; Sumarmi et al., 2020; Utami et al., 2016; Winaya et al., 2016) that assigning or 
providing a project-based learning module was very useful because researchers and students could focus on the project implementation. It is also supported by research (Budiningarti et al., 2015) that students' skills in developing learning media by using problem-based learning models were in the range of 77.94-97.06 of 0-100 scale with an average of 87.04 which means good.

The research (Delita et al., 2016) also aligned with this study that there was a significant correlation between the skills in developing learning media carried out by students and the skills in implementing learning. The results showed that there was an increase in soft skills indicators such as oral communication (0.54), participation (0.92), honesty $(0.42)$ and creativity (1.4). Furthermore, there was also increase to students who received A score in Cycle II, which is 8 people (up $25 \%$ of the total students) and B score increased to 2 people (up $6 \%$ of the total students). Hard skills indicators such as the ability to design learning tools and media also increased in Cycle II, which 21 people $(68 \%)$ in the excellent category and 10 people $(32 \%)$ in the good category. Students gave positive responses to the application of project-based learning in Geography Learning Planning subject (Marni et al., 2019; Muskania \& Wilujeng, 2017; Rafiola et al., 2020; Rasmitadila et al., 2020; Sari et al., 2019; Sumarmi et al., 2020).

\section{CONCLUSION}

From the results above, the research concluded: 1) The use of e-module was compatible with blended leaarning in disaster management discourse. 2) The use of e-modules with blended learning has a significant effect on student preparedness for disasters, especially in topic about flood, earthquake and covid-19. It can be seen from the mean gain score of the experimental group was higher and significantly different from the mean of the control group. 3) The students' innovation ability in designing learning media differed significantly between the control group and the experimental group. It can be seen from the mean gain score of the experimental group was higher and significantly different from the mean gain score of the control group. This study provided a solution to the prospective teacher students to design learning media. Further research can be developed by applying blended learning to other teaching skills, such as communication and presentation skills, collaboration, and critical thinking.

\section{ACKNOWLEDGEMENT}

This work was supported by PNBP research grant of State University of Malang.

\section{REFERENCES}

Abdillah, A. J., Rany, T. D., Kuswanto, H., \& Riyadi, I. (2020). Implementation of physics learning media based on android integrated earthquake disaster education to enhance problem solving abilities and natural disaster preparedness. Journal of Physics: Conference Series, 1440, 012027. https://doi.org/10.1088/1742-6596/1440/1/012027

Amin, S., Sumarmi, S., Bachri, S., Susilo, S., \& Bashith, A. (2020). The Effect of Problem-Based Hybrid Learning (PBHL) Models on Spatial Thinking Ability and Geography Learning Outcomes. International Journal of Emerging Technologies in Learning (IJET), 15(19), 83-94. https://doi.org/10.3991/ijet.v15i19.15729 
Arikunto, S. (2010). Prosedur Penelitian [Reseacrh Procedure], PT. Rineka Cipta, Jakarta.

Arizen, A., \& Suhartini, S. (2020). Mobile learning student worksheet based on socioscientific-issues: Enhancing students' scientific literacy skills in biology. JPBI (Jurnal Pendidikan Biologi Indonesia), 6(1), 15-24. https://doi.org/10.22219/jpbi.v6i1.11196.

Bachri, S., Stötter, J., Monreal, M., \& Sartohadi, J. (2015a). The calamity of eruptions, or an eruption of benefits? Mt. Bromo human-volcano system a case study of an openrisk perception. Natural Hazards and Earth System Sciences, 15(2), 277-290. https://doi.org/10.5194/nhess-15-277-2015

Bachri, S., Stötter, J., Monreal, M., \& Sartohadi, J. (2015b). The calamity of eruptions, or an eruption of benefits? Mt. Bromo human-volcano system a case study of an openrisk perception. Natural Hazards and Earth System Sciences, 15(2), 277-290. https://doi.org/10.5194/nhess-15-277-2015

Bachri, Syamsul, Sumarmi, Irawan, L. Y., Aldianto, Y. E., Fathoni, M. N., Fawaid, A. M., Utomo, K. S. B., \& Nuraini, S. G. (2020). Analysis of the Badeng River Storage Capacity for Flood Modeling in Singojuruh Subdistrict, Banyuwangi Regency. IOP Conference Series: Earth and Environmental Science, 412, 012030. https://doi.org/10.1088/1755-1315/412/1/012030

Bachri, Syamsul, Sumarmi, Yudha Irawan, L., Utaya, S., Dwitri Nurdiansyah, F., Erfika Nurjanah, A., Wahyu Ning Tyas, L., Amri Adillah, A., \& Setia Purnama, D. (2019). Landslide Susceptibility Mapping (LSM) in Kelud Volcano Using Spatial Multi-Criteria Evaluation. IOP Conference Series: Earth and Environmental Science, 273, 012014. https://doi.org/10.1088/1755-1315/273/1/012014

Bruning, R., \& Horn, C. (2000). Developing Motivation to Write. Educational Psychologist, 35(1), 25-37. https://doi.org/10.1207/S15326985EP3501_4

Budiarti, S., Nuswowati, M., \& Cahyono, E. (2016). Guided Inquiry Berbantuan EModul Untuk Meningkatkan Keterampilan Berpikir Kritis (Guided Inquiry Assisted by E-Modules to Improve Critical Thinking Skills). Journal of Innovative Science Education, 5(2), 144-151.

Budiningarti, H., Suprapto, N., \& Admoko, S. (2015). Peningkatan Kemampuan Mahasiswa Dalam Mengembangkan Perangkat Pembelajaran Fisika Melalui Penelaahan Perangkat Pembelajaran Berdasarkan Masalah (Students' Ability in Developing Physics Learning Media Through Study of Problem Based Learning). Jurnal Penelitian Fisika Dan Aplikasinya (JPFA), 5(2), 56-63. https://doi.org/10.26740/jpfa.v5n2.p56-63

Burhendi, F. C. A., L, W. D., Kusdiwelirawanc, A., \& Sagita, D. D. (2019). Implementation of Blended Learning to Use Discovery Learning Method. International Journal of Innovation, Creativity and Change, 5(6), 11.

Delita, F., Yetti, E., \& Sidauruk, T. (2016). Peningkatan Soft Skills Dan Hard Skills Mahasiswa Melalui Project-Based Learning Pada Mata Kuliah Perencanaan 
Pembelajaran Geografi (Improvement of students' soft skills and hard skills through project-based learning in Geography learning planning courses). JURNAL GEOGRAFI, 8(2), 124-135. https://doi.org/10.24114/jg.v8i2.5776

Garrison, D. R., \& Vaughan, N. D. (2008). Blended Learning in Higher Education: Framework, Principles, and Guidelines. John Wiley \& Sons.

Gibbons, M. M., \& Woodside, M. (2014). Addressing the Needs of First-Generation College Students: Lessons Learned From Adults From Low-Education Families. Journal of College Counseling, 17(1), 21-36. https://doi.org/10.1002/j.2161-1882.2014.00045.x

Ju, S. Y., \& Mei, S. Y. (2018). Perceptions and Practices of Blended Learning in Foreign Language teaching at USIM. European Journal of Social Sciences Education and Research, 12(1), 170. https://doi.org/10.26417/ejser.v12i1.p170-176

Lee, Y. C., Lau, K., \& Yip, V. W. Y. (2016). Blended learning for building studentteachers' capacity to learn and teach science-related interdisciplinary subjects: The case of Hong Kong. Asian Association of Open Universities Journal, 11(2), 166-181. https://doi.org/10.1108/AAOUJ-09-2016-0029

Lesmana, C., \& Purborini, N. (2015). Kesiapsiagaan Komunitas Sekolah dalam Menghadapi Bencana di Kabupaten Magelang (School Community Preparedness in Dealing with Disasters in Magelang District). Jurnal Teknik Sipil, 11(1), 15-28. https://doi.org/10.28932/jts.v11i1.1396

Marni, S., Suyono, S., Roekhan, R., \& Harsiati, T. (2019). Critical Thinking Patterns of First-Year Students in Argumentative Essay. Journal for the Education of Gifted Young Scientists, 7(3), 733-747. https://doi.org/10.17478/jegys.605324

Maryanti, S., Lestari, E., Putri, W., Wardani, A. R., \& Haris, F. (2017). Hubungan Tingkat Pendidikan Masyarakat terhadap Kesiapsiagaan Bencana Tanah Longsor di Kelurahan Giritirto Kecamatan Wonogiri (The Relation of community education level to landslide disaster preparedness in Giritirto sub-district, Wonogiri sub-district). http://publikasiilmiah.ums.ac.id/handle/11617/9019

Maryuningsih, Y., Hidayat, T., Riandi, R., \& Rustaman, N. (2019). Developing Gen$21 \mathrm{cs}$ on smartphone to cultivate the 21 st-century skills on biology teacher candidates. JPBI (Jurnal Pendidikan Biologi Indonesia), 5(3), 415-424. https://doi.org/10.22219/jpbi.v5i3.9714

Muskania, R. T., \& Wilujeng, I. (2017). Pengembangan Perangkat Pembelajaran Project-based Learning untuk Membekali Foundational Knowledge dan Meningkatkan Scientific Literacy (Development of Project-Based Learning Tools for Equipping Foundational Knowledge and Enhancing Scientific Literacy). Cakrawala Pendidikan, 1, 34-43. https://doi.org/10.21831/cp.v36i1.8830

Nonthamand, N. (2020). Guideline to Develop an Instructional Design Model Using Video Conference in Open Learning. International Journal of Emerging Technologies in Learning (IJET), 15(03), 140-155. https://doi.org/10.3991/ijet.v15i03.10842. 
Nurkhin, A., Kardoyo, K., Pramusinto, H., Setiyani, R., \& Widhiastuti, R. (2020). Applying Blended Problem-Based Learning to Accounting Studies in Higher Education; Optimizing the Utilization of Social Media for Learning. International Journal of Emerging Technologies in Learning (IJET), 15(08), 22-39. https://doi.org/10.3991/ijet.v15i08.12201

Otoluwa, Y., Eraku, S., \& Yusuf, D. (2020). Pengembangan Media Pembelajaran Berbasis Lectora Inspire yang Diintegrasikan dengan Camtasia Studio pada Mata Pelajaran Geografi Materi Sistem Informasi Geografi (Development of Learning Media Based on Lectora Inspire which is integrated with Camtasia Studio in Geography Subjects, Geographic Information Systems Material). Jambura Geo Education Journal, 1(1), 01-08. https://doi.org/10.34312/jgej.v1i1.4041

Permana, S. A. (2020). Merapi's Sacred Advice as a Warning of the Volcanic Eruption Disaster. International Journal of Innovation, Creativity and Change, 11(10), 15.

Rachmawati, I., Feranie, S., Sinaga, P., \& Saepuzaman, D. (2018). Penerapan Pembelajaran Berbasis Proyek Untuk Meningkatkan Keterampilan Berpikir Kreatif Ilmiah Dan Berpikir Kritis Ilmiah Siswa Sma Pada Materi Kesetimbangan Benda Tegar (Application of Project-Based Learning to Improve Scientific Creative Thinking Skills and Critical Thinking Skills of Senior High School Students on Equivalent Material of Hard Objects). WaPFi (Wahana Pendidikan Fisika), 3(2), 25. https://doi.org/10.17509/wapfi.v3i2.13725

Rafiola, R. H., Setyosari, P., Radjah, C. L., \& Ramli, M. (2020). The Effect of Learning Motivation, Self-Efficacy, and Blended Learning on Students' Achievement in The Industrial Revolution 4.0. International Journal of Emerging Technologies in Learning (IJET), 15(08), 71-82. https://doi.org/10.3991/ijet.v15i08.12525.

Rahardjanto, A., Husamah, H., \& Fauzi, A. (2019). Hybrid-PjBL: Learning Outcomes, Creative Thinking Skills, and Learning Motivation of Preservice Teacher. International Journal of Instruction, 12(2), 179-192. https://doi.org/10.29333/iji.2019.12212a.

Rasmitadila, R., Widyasari, W., Humaira, M. A., Tambunan, A. R. S., Rachmadtullah, R., \& Samsudin, A. (2020). Using Blended Learning Approach (BLA) in Inclusive Education Course: A Study Investigating Teacher Students' Perception. International Journal of Emerging Technologies in Learning (IJET), 15(02), 72-85. https://doi.org/10.3991/ijet.v15i02.9285

Ridwan, R., Hamid, H., \& Aras, I. (2020). Blended Learning in Research Statistics Course at The English Education Department of Borneo Tarakan University. International Journal of Emerging Technologies in Learning (IJET), 15(07), 61. https://doi.org/10.3991/ijet.v15i07.13231

Roberts, R. (2009). Video Conferencing in Distance Learning: A New Zealand Schools' Perspective. Journal of Open, Flexible, and Distance Learning, 13(1), 91-107. 
Roe, D., Carley, S., \& Sherratt, C. (2010). Potential and limitations of e-learning in emergency medicine. Emergency Medicine Journal, 27(2), 100-104. https://doi.org/10.1136/emj.2008.064915

Rosyida, F., \& Adi, K. R. (2017). Studi eksplorasi pengetahuan dan sikap terhadap kesiapsiagaan bencana banjir di SD Pilanggede Kecamatan Balen Kabupaten Bojonegoro (Exploration Study of Knowledge and Attitudes Towards Flood Disaster Preparedness in Pilanggede Primary School, Balen District, Bojonegoro Regency). Jurnal Teori Dan Praksis Pembelajaran IPS, 2(1), 1-5.

Sari, R. M., Sumarmi, S., Astina, I. K., Utomo, D. H., \& Ridhwan, R. (2019). Measuring Students Scientific Learning Perception and Critical Thinking Skill Using Paper-Based Testing: School and Gender Differences. International Journal of Emerging Technologies in Learning (IJET), 14(19), 132-149. https://doi.org/10.3991/ijet.v15i08.12525.

Shah, A. A., Ye, J., Abid, M., Khan, J., \& Amir, S. M. (2018). Flood hazards: Household vulnerability and resilience in disaster-prone districts of Khyber Pakhtunkhwa province, Pakistan. Natural Hazards, 93(1), 147-165. https://doi.org/10.1007/s11069-018-3293-0

Sholihah, Q., Fhaiz, I. M. N., Aulanni'am, Kuncoro, W., Novareza, O., \& Yuniarti, R. (2019). An Analysis of the Knowledge of Disaster Preparedness and Occupational Health and Safety (OHS) Promotion on Earthquake Disaster Preparedness. International Journal of Innovation, Creativity and Change, 7(9), 10.

Sorokin, R., \& Rougier, J.-L. (2018). Video conference in the fog: An economical approach based on enterprise desktop grid. Annals of Telecommunications, 73(5), 305316. https://doi.org/10.1007/s12243-017-0613-4

Stein, J., \& Graham, C. R. (2020). Essentials for Blended Learning, 2nd Edition: A Standards-Based Guide. Routledge.

Suarsana, I. M., \& Mahayukti, G. A. (2013). Pengembangan E-Modul Berorientasi Pemecahan Masalah Untuk Meningkatkan Keterampilan Berpikir Kritis Mahasiswa (Development of E-Modules based on Problem-solving to Improve Critical Thinking Skills). JPI (Jurnal Pendidikan Indonesia), 2(2), Article 2. https://doi.org/10.23887/jpiundiksha.v2i2.2171

Sugiani, K. A., Degeng, I. N. S., Setyosari, P., \& Sulton. (2019). The Effects of Electronic Modules in Constructivist Blended Learning Approaches to Improve Learning Independence. International Journal of Innovation, Creativity and Change, 9(10), 12.

Suharto, N. T., Ph, S., Jaedun, A., \& Purwanta, H. (2020). The Effectiveness of a School-Based Disaster Risk Reduction Program in Indonesia: A Case Study in the Klaten Regency's Junior High Schools. International Journal of Innovation, Creativity and Change, 12(12), 14. 
Suharyati, H., Vonti, L. H., Suhardi, E., \& Sunardi, O. (2020). Promoting Knowledge Management Approach and Active Learning Model in Blended Learning Activities of Higher Education. International Journal of Innovation, Creativity and Change,, 12(9), 20 .

Sukhothai Thammathirat Open University (STOU). (2019). STOU Distance Learning System. https://www.stou.ac.th/main/en/distance.html

Sumarmi. (2015). Local Wisdom of Osing People in Conserving Water Resources. Komunitas: International Journal of Indonesia Society and Culture, 7(1), 43. https://doi.org/10.15294/komunitas.v7i1.3429

Sumarmi. (2017). Influence of Local Wisdom-Based Blended Learning Module for Environmental Geography Towards Problem-Solving Skill. 157-160. https://doi.org/10.2991/icli-17.2018.30

Sumarmi, S. (2012). Model-Model Pembelajaran Geografi (Geography Learning Models). Aditya Media.

Sumarmi, S. (2018). Understanding the Forest Conservation Society actions "Tengger" ethnic Based Local Wisdom "Sesanti Panca Setya" in East Java-The Republic of Indonesia. 1623-1627. https://doi.org/10.2991/icss-18.2018.337

Sumarmi, S., Bachri, S., Baidowi, A., \& Aliman, M. (2020). Problem-Based Service Learning's Effect on Environmental Concern and Ability to Write Scientific Papers. International Journal of Instruction, 13(4). https://doi.org/10.29333/iji.2020.13411a

Sumarmi, S., Bachri, S., \& Tanjung, A. (2019). Madurese Fishermen's Adaptation to Marine Environment-Based Approach in Fisheries Resources Management by Empowering the Local Wisdom of “Onjem." 107-114. https://doi.org/10.2991/icskse18.2019 .21

Sumarmi, S., Bachri, S., Yuda Irawan, L., Perdana Putra, D. B., Risnani, R., \& Aliman, M. (2020). The Effect of Experiential Learning Models on High School Students Learning Scores and Disaster Countermeasures Education Abilities. Journal for the Education of Gifted Young Scientists, 61-85. https://doi.org/10.17478/jegys.635632

Thomas, P. Y. (2010). Towards developing a web-based blended learning environment at the University of Botswana [Thesis, University of South Africa]. http://uir.unisa.ac.za/handle/10500/4245

Utami, W. S., Sumarmi, Ruja, I. N., \& Utaya, S. (2016). The Effectiveness of Geography Student Worksheet to Develop Learning Experiences for High School Students. Journal of Education and Learning, 5(3), 315-321. http://dx.doi.org/10.5539/jel.v5n3p315

Wahyuni, S., Sanjaya, I. G. M., Erman, E., \& Jatmiko, B. (2019). Edmodo-Based Blended Learning Model as an Alternative of Science Learning to Motivate and Improve Junior High School Students' Scientific Critical Thinking Skills. International 
Journal of Emerging Technologies in Learning (IJET), 14(07), 98-110. https://doi.org/10.3991/ijet.v14i07.9980

Westen, C. J., \& Montoya, L. (2011). Multi-hazard risk assessment Distance education course. Guide book. ITC Faculty of Geo-information Science and Earth Observation.

Wichadee, S. (2017). A Development of the Blended Learning Model Using Edmodo for Maximizing Students' Oral Proficiency and Motivation. International Journal of $\begin{array}{lllll}\text { Emerging Technologies in Learning (IJET), } & 12(02),\end{array}$ https://doi.org/10.3991/ijet.v12i02.6324

Winaya, I. K. A., Darmawiguna, I. G. M., \& Sindu, I. G. P. (2016). Pengembangan EModul Berbasis Project Based Learning Pada Mata Pelajaran Pemrograman Web Kelas X Di SMK Negeri 3 Singaraja (The Development of E-Modules based on Project-Based Learning in Web Programming Subjects of Class X in Vocational High School 3 Singaraja). Jurnal Pendidikan Teknologi Dan Kejuruan, 13(2), 198-211. https://doi.org/10.23887/jptk-undiksha.v13i2.8527 